\title{
The manifestation of tsunami of August 1, 1940 in the Kamenka settlement, Primorye (new data concerning the old tsunami)
}

\author{
Victor M. Kaistrenko*1 \\ Nadezhda G. Razjigaeva ${ }^{2}$ \\ Larisa A. Ganzey ${ }^{2}$ \\ Alexey O. Gorbunov ${ }^{1}$ \\ Yuichi Nishimura ${ }^{3}$
}

\author{
${ }^{1}$ Institute of Marine Geology and Geophysics, FEB RAS, \\ Yuzhno-Sakhalinsk, Russia \\ ${ }^{2}$ Pacific Institute of Geography, FEB RAS, Vladivostok, Russia \\ ${ }^{3}$ Institute of Volcanology and Seismology, Hokkaido University, \\ Sapporo, Japan \\ *E-mail:vict-k@mail.ru
}

\begin{abstract}
Peферат PDF Rus
One of the most powerful earthquakes in the Sea of Japan area happened on August 1, 1940. This earthquake had been accompanied by a large tsunami in the Northern part of the sea. The article contains the description of an unusual feature of the 1940 Japan Sea tsunami manifestation: maximum tsunami run-up heights were observed in the far-field zone (Primorye coast, Russia), not in the near-field zone (Hokaido coast, Japan). Description of the striking manifestation of this tsunami with run-up heights up to $5 \mathrm{~m}$ in the vicinity of the Kamenka settlement in Primorye is based on the information from eyewitness and their descendants. These data were not mentioned in the tsunami catalogues and are thus news for tsunami science. Three torpedo motor-boats had been displaced by the tsunami from the Kamenka harbor to the peat area far from the sea. Corresponding map is shown.
\end{abstract}

\section{Keywords}

Sea of Japan, Primorye, Hokkaido, Kamenka settlement, earthquake, tsunami, run-up height

For citation: Kaistrenko V.M., Razjigaeva N.G., Ganzey L.A., Gorbunov A.O., Nishimura Yu. The manifestation of tsunami of August 1, 1940 in the Kamenka settlement, Primorye (new data concerning the old tsunami). Geosystems of Transition Zones, 2019, vol. 3, no. 4. P. 417-422 (In Englich, abstract in Russian) https://doi.org/10.30730/2541-8912.2019.3.4.417-422

Для цитирования: Кайстренко В.М., Разжигаева Н.Г., Ганзей Л.А., Горбунов А.О., Нисимура Ю. Проявления цунами 1 августа 1940 г в Каменке, Приморье (новые данные о давнем историческом цунами). Геосистемы переходных зон. 2019. Т. 3, № 4. С. 417-422. (На англ. яз., реферат на русском) https://doi.org/10.30730/2541-8912.2019.3.4.417-422

\section{References}

1. Abe K., Ishii H. 1987. Distribution of maximum water levels due to the Japan Sea Tsunami on 26 May 1983. Journal of the Oceanographical Society of Japan. 43: 169-182. https://doi.org/10.1007/BF02109217

2. Go Ch. N., Ivashchenko A.I., Simonov K.V., Soloviev S.L. 1985. Manifestation of the Japan Sea tsunami of the 26 May, 1983 on the USSR coast. In: Tsunami run-up on the coast. Gorkiy: IAP AS USSR. P. 171-180. (In Russian)

3. Gorbunova G.V., Didenko G.V., Dyachenko V.D., Nagornyh T.V., Poplavskiy A.A., Poplavskaya L.N. 1997. The survey of the tsunami 12-13 July, 1993 on the Primorye coast. In: Concrete Tsunami Manifestation. Tsunamis of the 1993 and 1994 on the Russian coast. Yuzhno-Sakhalinsk: IMGG FEB RAS. 8: 7-28. (Geodynamics of tectonosphere of the Pacific-Eurasia conjunction zone: in 8 vol.). (In Russian)

4. Hatori, T. 1969. A study of the wave source of tsunami generated off west Hokkaido on Aug. 2, 1940. Bulletin of the Earthquake Research Institute, Tokyo Univ. 47: 1063-1072. 
5. Hatori T. 1983. Tsunami magnitude and source area of the Nihonkai-Chubu (the Japan Sea) Earthquake in 1983. Bulletin of the Earthquake Research Institute, Tokyo Univ. 58: 723-734. (Text in Japanese, abstract and figures and tables are in English)

6. Hatori T. 1991. Distribution of Tsunami Heights in the USSR and Korea for Tsunamis generated in the Japan Sea. Bulletin of the Earthquake Research Institute, Tokyo Univ. 66: 571-584 (Text in Japanese, abstract and figures and tables are in English)

7. HTDB/WLD: Historical Tsunami Database for the World Ocean. URL: http://tsun.sscc.ru/htdbpac/ (accessed: 15.09.2014).

8. Miyabe N. 1940. Tsunami associated with the Northern Japan Sea earthquake of Aug. 2, 1940. Zisin (Journal of the Seismological Society of Japan). 12(12): 535-556 (In Japanese)

9. Miyabe N. 1941. Tsunami associated with the earthquake of August 2, 1940. Bulletin of the Earthquake Research Institute, Tokyo Univ. 19: 104-114 (In Japanese, abstract in English)

10. NGDC: Tsunami Data and Information. URL: https://www.ngdc.noaa.gov/hazard/tsu_db.shtml (accessed: 29.09.2019). doi:10.7289/V5PN93H7

11. Polyakova A.M. 1988. Tsunami of May 26, 1983 in Primorye and its effects. Vladivostok: POI FEB RAS. 37 p. (In Russian)

12. Shchetnikov N.A. 1981. Tsunamis. M.: Nauka. 88 p. (In Russian)

13. Soloviev S.L., Go Ch.N. 1984. Catalogue of tsunamis on the western shore of the Pacific Ocean (173-1968). Canada Inst. for Scientific and Techn. Inform. Ottawa, Ontario, Canada: National Res. Council. 447 p. (Canadian Translation of Fisheries and Aquatic Sciences; no. 5077). Translated from Soloviev S.L., Go Ch.N. 1974. A catalogue of tsunamis on the western shore of the Pacific Ocean (173-1968). Moscow: Nauka. 310 p. (In Russian)

14. The 2 August, 2007 Nevelsk Sakhalin Island earthquake and tsunami. Ed. by B.W. Levin and I.N. Tikhonov. 2009. Moskow: Yanus-K. 204 p. (In Russian)

15. Tikhonov I.N. 2006. Large earthquakes in the Sakhalin district: investigations and predictions. Vestnik DVO RAN. 1: 67-80. (In Russian) 